Chu, Pao-Shin, 1988: Extra-tropical forcing and athe burst of equatorial westerlies in the western Pacific: A synoptic study. J. Meteor. Soc. Japan, 66, 549-564.

Hahn, D.G., and J. Shukla, 1976: An apparent relationship between Eurasian snow cover and Indian monsoon rainfall. J. Atmos. Sci., 33, 2461-2462.

Krishnamurti, T.N., W.J. Koss and J.D. Lee, 1973: Tropical eastwest circulations during the northern winter. J. Atmos. Sci., 30, 780-787.

Lau, K.M., and P.H. Chan, 1986: The 40-50-day oscillation and the El Niño/southern oscillation: A new perspective. Bull. Amer. Meteor. Soc., 67, 533-534.

_ , and _ 1988: Interannual and intraseasonal variations of tropical convection: A possible link between the 40-50-day oscillation and ENSO? J. Atmos. Sci., 44, 506-521.

Meehl, G.A., 1987: The annual cycle and interannual variability in the tropical Pacific and Indian Ocean region. Mon. Wea. Rev., 115, 27-50.

Nitta, T.S., 1989: Development of a twin cyclone and westerly bursts during the initial phase of the 1986-87 EI Niño. J. Meteor. Soc. Japan, 67, 677-681.

Parthasarathy, B., 1987: Droughts/floods in the summer monsoon season over different meteorological subdivisions of India for the period 1871-1984. J. Climatol., 7, 57-70.

Rasmusson, E.M., and T.H. Carpenter, 1982: Variations in tropical sea surface temperature and surface wind fields associated with the southern oscillation/EI Niño. Mon. Wea. Rev., 110, 354-384.

_- X. Wang and C.F. Ropelewski, 1990: The biennial component of ENSO variability. Submitted to J. Marine Sys.

Ropelewski, C.F., and M.S. Halpert, 1989: Precipitation patterns associated with the high index phase of the southern oscillation. J. Climatol., 2, 268-284.
Russell, R.J., 1934: Climatic years. Geogr. Rev., 24, 92-103.

Shukla, J., and D.A. Paolino, 1983: The southern oscillation and long-range forecasting of the summer monsoon rainfall over India. Mon. Wea. Rev., 111, 1830-1837.

Sumi, A., 1986: On the movement of the "convection center" from summer to winter season in the Northern Hemisphere. J. Meteor. Soc. Japan, 64, 605-611.

Troup, A.J., 1965: The "southern oscillation." Quart. J. Roy. Meteor. Soc., 91, 490-506.

Walker, G.T., and E.W. Bliss, 1932: World weather V. Mem. Roy. Meteor. Soc., 4, 53-84.

Yamagata, T., and Y. Masumoto, 1989: A simple air-sea coupled model of the origin of a warm ENSO event. Phil. Trans. Roy. Soc. London, A329, 225-236.

Yasunari, T., 1981: Temporal and spatial variations of monthly rainfall in Java, Indonesia. Southeast Asian Studies, 19, 170186.

_ 1987: Global structure of the El Nino/southern oscillation. Part II. Time evolution. J. Meteor. Soc. Japan, 65, 81-82.

- 1989: A possible link of the QBOs between the stratosphere, troposphere, and the sea surface temperature in the tropics. $J$. Meteor. Soc. Japan, 67, 483-493.

_ 1990: Impact of Indian monsoon on the coupled atmosphere/ ocean system in the tropical Pacific. Meteor. Atmos. Phys., 44, 29-41.

- and R. Suppiah, 1988: Some problems on the interannual variability of Indonesian monsoon rainfall. Tropical Rainfall Measurements, J.S. Theon and N. Fugono, Eds., A. Deepak Publishing, 113-121.

\title{
Addendum to Directory of Local Chapters
}

\author{
(Bull. Amer. Meteor. Soc., 72, 1262-1269)
}

The following is a listing of local chapters of the American Meteorological Society not included in the Organization Issue of the Bulletin (August 1991).

\section{Arizona}

University of Arizona in Tucson Chapter Address all correspondence to: William D. Sellers Department of Atmospheric Sciences The University of Arizona Tucson, AZ 85721

\section{Florida}

Northwest Florida Chapter

\author{
West Palm Beach Chapter \\ Address all correspondence to: \\ Jeffrey S. Tongue \\ South Florida Water Management District \\ P.O. Box 24680 \\ 3301 Gun Club Road \\ West Palm Beach, FL 33416-4680
}

\section{Georgia, South Carolina}

Georgia, South Carolina Chapter

\section{Tennessee}

Tennessee Valley Chapter

(currently inactive)

\section{Texas}

West Texas Chapter 